\title{
Torsional fatigue strength of reciprocating and rotary pathfinding instruments manufactured from different NiTi alloys
}

\author{
Rodrigo Ricci VIVAN(a) \\ Murilo Priori ALCALDE(a) iD \\ George CANDEIRO(b) ID \\ Giulio GAVINI(c) iD \\ Celso Luis CALDEIRA(c) \\ Marco Antonio Hungaro \\ DUARTE(a) $^{(\mathrm{D}}$ \\ (a) Universidade de São Paulo - USP, Bauru \\ School of Dentistry, Department of \\ Operative Dentistry, Endodontics, and \\ Dental Materials, Bauru, SP, Brazil. \\ (b) Centro Universitário Unichristus, School of \\ Dentistry, Fortaleza, CE, Brazil. \\ (c) Universidade de São Paulo - USP, School \\ of Dentistry, Department of Operative \\ Dentistry, São Paulo, SP, Brazil.
}

Declaration of Interests: The authors certify that they have no commercial or associative interest that represents a conflict of interest in connection with the manuscript.

Corresponding Author:

Rodrigo Ricci Vivan

E-mail: rodrigo.vivan@fob.usp.br

https://doi.org/10.1590/1807-3107bor-2019.vol33.0097

Submitted: March 7, 2019

Accepted for publication: September 1, 2019 Last revision: September 24, 2019

\begin{abstract}
To evaluate the torsional properties of engine-driven pathfinding instruments manufactured from different NiTi alloys R-Pilot (tip size 12.5;.04 taper; M-Wire) and One G (tip size 14;.03 taper; Conventional NiTi). A total of $40 \mathrm{NiTi}$ instruments from engine-driven pathfinding instruments $(n=20)$ were used. The torsion tests followed ISO 3630-1 (1992). Three millimeters of each instrument tip was fastened to a small load cell by a lever arm linked to the axis of torsion. During the test, the torsion testing machine software measured the maximum torsional strength and angle of rotation $\left(^{0}\right)$ before instrument failure. The fractured surface of each instrument was assessed by scanning electron microscopy (SEM). In addition, a supplementary examination was performed to measure the cross-sectional area and the metal mass volume of each instrument $3 \mathrm{~mm}$ from the tip. Data were analyzed using a t-test, with significance level set at 5\%. R-pilot had significantly higher torsional strength than did One $G(p<0.05)$. Regarding the angle of rotation to fracture, One $G$ had higher angles than did R-Pilot $(p<0.05)$. The supplementary examination showed that R-Pilot had the highest cross-sectional area and volume of metal mass at $3 \mathrm{~mm}$ from the tip ( $\mathrm{p}<0.05)$. R-pilot (M-Wire NiTi alloy) had a significantly higher torsional strength and One-G (superelastic NiTi alloy) had the highest angle of rotation to fracture.
\end{abstract}

Keywords: Endodontics; Root Canal Preparation; Dental Instruments.

\section{Introduction}

During root canal preparation, maintenance of the original canal anatomy is mandatory to avoid undesirable shaping errors. ${ }^{1,2}$ The glide path is an endodontic procedure that aims to pre-enlarge the root canal from its orifice to its apical constrictions prior to root canal preparation with hand or engine-driven NiTi instruments. ${ }^{3,4}$ Additionally, the glide path favors less canal transportation, ${ }^{5,6}$ prevents shaping errors, ${ }^{1,3,7}$ decreases the mechanical stress of engine-driven NiTi instruments, $5,7,8$ and reduces postoperative pain. ${ }^{7,8}$ Therefore, it has been strongly recommended during root canal preparation, especially for curved and constricted canals. ${ }^{4,5,7}$ 
The glide path can be performed using conventional stainless steel \#10 hand files and rotary and reciprocating NiTi instruments with small tip sizes and small tapers.,10,11 Pathfinding instruments are used at the beginning of canal preparation and could be subject to high torsional loads, increasing the risk of plastic deformation or instrument failure. ${ }^{2,12,13}$ Torsional failure occurs when the cutting blades of the instruments are locked in the dentin walls while the shank continues to rotate. ${ }^{14}$ Thus, it is essential that the torsional properties of pathfinding instruments be evaluated.

Several NiTi pathfinding instruments present different cross-sectional designs, taper, tip size, and thermomechanical treatments. ${ }^{2,10,15,16}$ One $G$ is a single-file pathfinding instrument manufactured from superelastic NiTi alloy. This instrument has an asymmetric cross-section with three cutting blades, $0.140 \mathrm{~mm}$ of tip size, and a constant. 03 taper. $^{17}$ Additionally, the cutting edges of One G have different pitches, which reduce the screwing effect ${ }^{17}$ and favor debris elimination. ${ }^{18,19}$

R-Pilot, the first reciprocating NiTi pathfinding instrument, has been recently introduced on the market. This instrument is made of M-Wire alloy, has an S-shaped cross-section, a 0.125-mm tip size and a.04 constant taper. Yilmaz et al. ${ }^{17}$ showed that R-Pilot presented higher cyclic fatigue resistance than did One G.

Despite the advantages of engine-driven pathfinding instruments, unexpected instrument failure is still a concern. ${ }^{7,13}$ The torsional properties of pathfinding instruments are affected by taper, tip size, cross-sectional design, and type of NiTi alloy. 2,13,20 Therefore, knowledge of the torsional properties of these instruments could help clinicians to choose a more suitable instrument for negotiation of a constricted canal.

The torsion test tries to simulate torsional stress during root canal preparation by clamping the instrument's tip and rotating it at a standardized speed. ${ }^{13,20}$ During the test, the maximum torsional strength and angle of rotation supported by the instrument before failure are measured. ${ }^{21,22}$ This test has been widely used to assess the torsional properties of endodontic instruments, and it has been previously reported by several authors. ${ }^{13,20,21,22}$
There is no study comparing the torsional properties of R-Pilot and One G instruments. The aim of this study was to evaluate the torsional properties (maximum torsional strength and angle of rotation) of R-Pilot and One G. The null hypothesis was that there would be no difference in the torsional properties between these instruments.

\section{Methodology}

Based on data from a previous study [22], the sample size was calculated using $G^{*}$ Power 3.1 (Heinrich Heine University, Düsseldorf, Germany). The calculation indicated that the sample should include at least 20 files per group.

Forty NiTi instruments ( $25 \mathrm{~mm}$ in length) from two different glide path systems ( $\mathrm{n}=20$ per system) were used in this study, as follows: R-pilot (tip size 12.5; .04 taper; M-Wire NiTi) and One G (tip size 14; .03 taper; Conventional NiTi). Before testing, all instruments were inspected under a stereomicroscope (Stemi 2000C; Carls Zeiss, Jena, Germany) at 16x magnification for detecting possible defects or deformities; none were discarded.

\section{Metal mass volume analysis}

Prior to the torsional test, all the instruments were scanned by Micro-CT (Skyscan 1174v2; Bruker-micro-CT, Kontich, Belgium) to evaluate the metal mass volume along the $3 \mathrm{~mm}$ tip. The Micro-CT parameters used were $50 \mathrm{KV}, 800 \mathrm{~mA}, 360^{\circ}$ of rotation, and an isotropic resolution of $14.1 \mu \mathrm{m}$. The images of each specimen were reconstructed with dedicated software (NRecon v. 1.6.3, Brukermicro-CT), which provided the three-dimensional analysis of the metal mass volume. The metal mass volume was then evaluated using the CTAn v.1.12 software (Bruker-micro-CT).

\section{Torsion test}

The torsion tests were performed in compliance with the International Organization for Standardisation ISO 3630-1 (1992) specification, using a torsion testing machine described in detail elsewhere. ${ }^{22,23,24}$ Before testing, all the instruments had their handles removed at the point where 
the handle was attached to the shaft. The shaft of each instrument was fixed into a chuck and connected to a geared motor. Three millimeters of the instrument's tip was fixed into another chuck, connected to a small load cell. The geared motor rotated at standardized speed $(2 \mathrm{rpm})$ in a clockwise direction for One $G$ instruments and in a counterclockwise direction for R-Pilot. The maximum torsional strength (N.cm) values and angle of rotation $\left(^{0}\right)$ before instrument failures were measured by the torsion testing machine software (Analógica, Belo Horizonte, Brazil).

\section{SEM Evaluation}

After the torsion test, the instruments were ultrasonically cleaned to remove debris and were examined by scanning electron microscopy (JEOL, JSM-TLLOA, Tokyo, Japan) to assess the topographic features of their fractured surface. The SEM evaluation was performed at 50x and 350x magnification. Furthermore, an additional assessment was performed at $1000 x$ magnification at the center of the fracture surface of the instruments to improve the analysis of the topographic features. In addition, the SEM images were used to measure the cross-sectional area of the instruments using the AutoCAD software (Autodesk Inc, San Rafael, USA), as previously reported. ${ }^{22,23,24}$

\section{Statistical analysis}

Preliminary analysis of data normality was performed with the Shapiro-Wilk test, which showed that the data were normally distributed. One-way analysis of variance (ANOVA) and Tukey's tests were used for multiple and individual comparisons. The Prism 6.0 software (GraphPad Software Inc., La Jolla, USA) was used as the analytical tool, and the level of significance was set at $5 \%$.

\section{Results}

The mean and standard deviations of torsional fatigue strength (maximum torsional strength and angle of rotation) of the instruments are shown in Table 1. R-Pilot had significantly higher torsional strength than did One $G(p<0.05)$. However, One
$G$ had a significantly higher angle of rotation to fracture than did R-Pilot ( $p<0.05)$. The mean and standard deviations of the cross-sectional area and metal mass volume at $3 \mathrm{~mm}$ from the tip are shown in Table 2. R-Pilot had a significantly higher cross-sectional area and volume of metal mass than did One G $(p<0.05)$.

TheSEM evaluation of the fracture surface revealed similar and typical features of torsional failure for both brands. All the instruments had concentric abrasion marks and fibrous dimple marks at the center of rotation for torsional failure (Figure A, B, C, and $\mathrm{D}$ ). In addition, in the lateral view, it is possible to note the deformation of the spiral flutes of the instruments, mainly in those that had a higher angle of rotation (Figure E and F).

\section{Discussion}

An effective glide path procedure can improve root canal preparation, reducing operational errors, ${ }^{6,7}$ risk of instrument failure, ${ }^{1,25}$ debris extrusion, and postoperative pain, ${ }^{8}$ and maintaining the original root canal anatomy. ${ }^{6}$ This procedure has been performed using a \#10 $\mathrm{K}$ hand file and

Table 1. Mean values of torque (N.cm) and angle of rotation $\left(^{\circ}\right)$ of the instruments tested.

\begin{tabular}{lcccc}
\hline \multirow{2}{*}{ Instruments } & \multicolumn{4}{c}{ Torsional Fatigue } \\
\cline { 2 - 5 } & \multicolumn{2}{c}{ Torque $(\mathrm{N} . \mathrm{cm})$} & \multicolumn{2}{c}{ Angles $\left(^{\circ}\right)$} \\
\cline { 2 - 5 } & Mean & SD & Mean & SD \\
\hline One G & $0.24^{\mathrm{b}}$ & 0.011 & $778.4^{\mathrm{b}}$ & 10.48 \\
R-Pilot & $0.51^{\circ}$ & 0.019 & $279.3^{\circ}$ & 6.35 \\
\hline
\end{tabular}

Different superscript letters in the same column indicate statistical differences between the groups ( $p<.05)$; SD: standard deviation.

Table 2. Mean values of cross-sectional area $\left(\mu \mathrm{m}^{2}\right)$ and metal mass volume $\left(\mathrm{mm}^{3}\right)$ for the $3 \mathrm{~mm}$ instrument tips.

\begin{tabular}{lcccc}
\hline \multirow{2}{*}{ Instruments } & \multicolumn{2}{c}{$\begin{array}{c}\text { Cross-sectional area } \\
\left(\mu \mathrm{m}^{2}\right)\end{array}$} & \multicolumn{2}{c}{$\begin{array}{c}\text { Metal mass volume } \\
\left(\mathrm{mm}^{3}\right)\end{array}$} \\
\cline { 2 - 5 } & Mean & SD & Mean & SD \\
\hline One G & $24.190^{\mathrm{b}}$ & 0.021 & $0.0308^{\mathrm{b}}$ & 0.0019 \\
R Pilot & $36.930^{\circ}$ & 0.009 & $0.0422^{a}$ & 0.0022 \\
\hline
\end{tabular}

Different superscript letters in the same column indicate statistical differences between the groups $(p<.05)$; SD: standard deviation. 

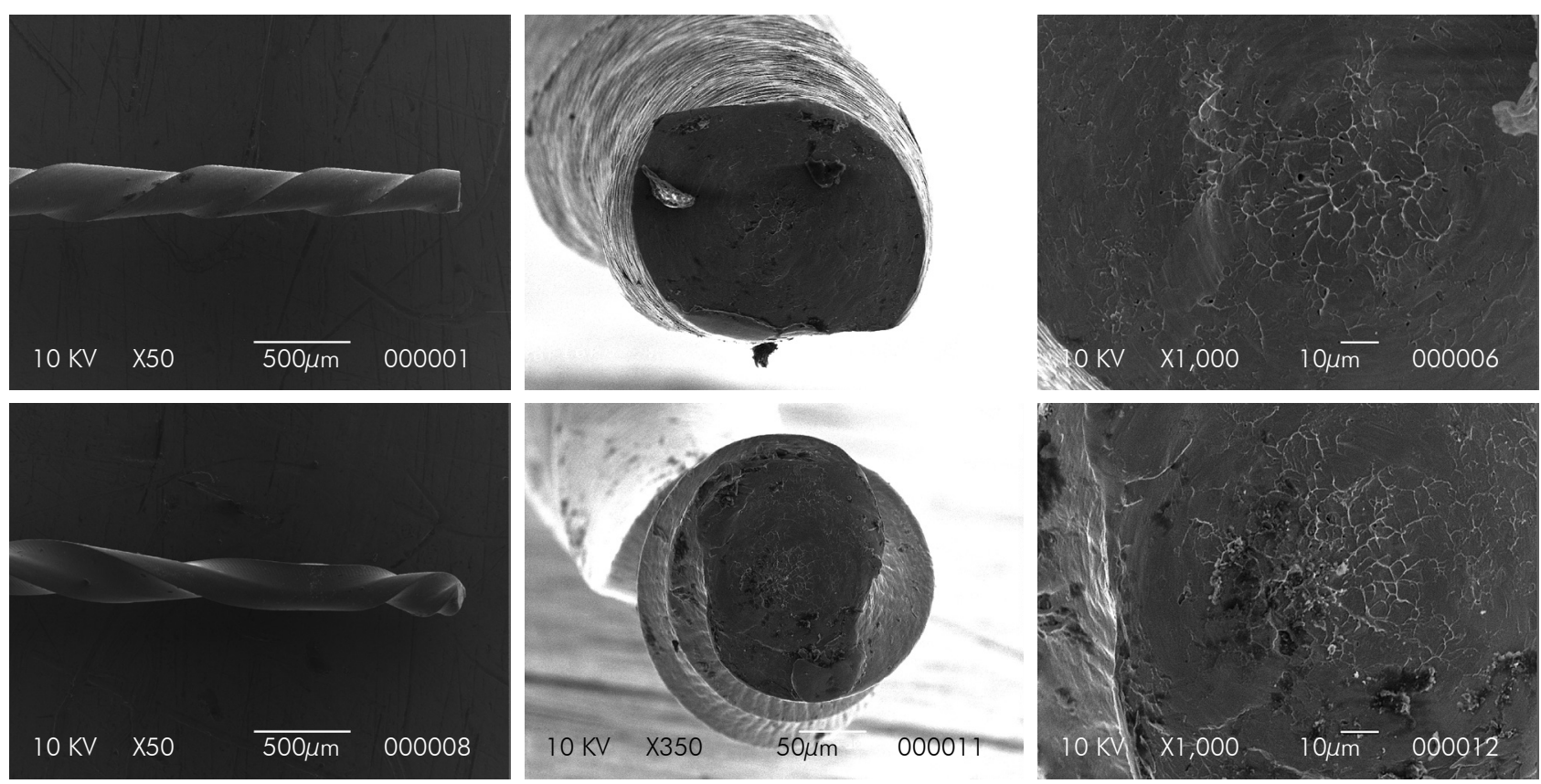

Figure. SEM images of fractured surfaces of R-Pilot $(A, C, E)$ and of One $G(B, D, F)$ after torsional fatigue testing. The first column shows the front view of the fracture surface of the instruments at $350 \mathrm{X}$ magnification; the second column shows the center of rotation with the concentric abrasion mark and skewed dimples at 1000x magnification, which are typical features of torsional failure; the third column represents the lateral view of the instruments at 50X magnification, showing the plastic deformation of the spiral flutes, especially of One G instrument.

NiTi engine-driven instruments. ${ }^{7,17}$ Currently, the use of engine-driven NiTi instruments has been proposed because these instruments can reduce the length of the procedure and possible difficulties associated with it. ${ }^{8,20}$ Several new NiTi pathfinding instruments have been introduced, with different designs, type of NiTi alloy, tapers, diameters, and kinematics. ${ }^{2,13,17}$ These different features can affect their clinical performance and mechanical properties. However, there is no information on the torsional properties of R-Pilot and One $G$ yet. Therefore, this study sought to fill this gap.

In this study, the torsion test was performed to assess the maximum torsional strength and angle of rotation supported by the instruments before failure. The test was performed according to ISO Standard 3630-1, which had been previously reported by several authors..$^{21,22,23,24}$ The $3 \mathrm{~mm}$ of the instrument's tip was fastened and rotation in a clockwise and counterclockwise direction was carried out for One G and R-Pilot, respectively. The
$3 \mathrm{~mm}$ of the instruments tip was chosen because this area is more prone to failure. ${ }^{27}$ This test ensures accurate results regarding torsional properties and is considered gold standard, used by several authors. ${ }^{21,22,23,24}$ The results of this study revealed that there was a significant difference in the torsional properties between the instruments tested. Thus, our null hypothesis was rejected.

Although laboratory studies do not simulate the actual clinical conditions, they could provide endodontists with important knowledge. ${ }^{17}$ The results revealed that R-Pilot had significantly higher torsional strength than did One $G(p<0.05)$. However, One $G$ presented higher rotation angle to fracture than did R-Pilot ( $\mathrm{p}<0.05)$. Even though the M-Wire NiTi alloy has greater flexibility in comparison with conventional $\mathrm{NiTi},{ }^{20,27,28}$ the results of this study showed that R-Pilot presented higher torsional strength and lower angle of rotation to fracture. Despite the lack of previous studies comparing the torsional properties between R-Pilot and One G, the torsional strength and 
angular rotation of these instruments are similar to those reported by other authors. ${ }^{29,30}$ The different torsional properties could be related to the different cross-sectional design, taper, and tip diameter between the instruments.

Previous studies have reported that instruments with greater metal mass volume and tip diameter tend to present higher torsional strength and lower angle rotation to failure. ${ }^{22,24,28,31}$ The metal mass volume is directly affected by the taper, cross-sectional design, and tip diameter of the instruments. ${ }^{31,32}$ Therefore, in a supplementary analysis, the cross-sectional design of the instruments was assessed by $3 \mathrm{D}$ to measure the cross-sectional area $\left(\mu \mathrm{m}^{2}\right)$. In addition, the metal mass volume $\left(\mathrm{mm}^{3}\right)$ of the $3 \mathrm{~mm}$ of instrument tips was measured by Micro-CT. Micro-CT is an accurate technology and has been used to assess the quality of root canal preparation, endodontic obturation, and root canal anatomy. ${ }^{33}$ There are no previous studies that have evaluated metal mass volume using this method. The results showed that R-Pilot presented a significantly larger cross-sectional area and metal mass volume than did One $\mathrm{G}(\mathrm{P}<0.05)$. Despite the smaller tip diameter of R-Pilot $(0.125 \mathrm{~mm} / \mathrm{mm})$ when compared to One $G(0.140 \mathrm{~mm} / \mathrm{mm})$, the cross-sectional design and lower taper (.03) of One G instruments favored a significantly lower metal mass volume and cross-sectional area, which could explain the torsional properties of R-Pilot instruments. Moreover, susceptibility to instrument failure is affected by the cross-sectional design because it can alter the stress distribution under torsion..$^{32,34}$

The SEM analysis demonstrated the typical features of torsional failure for all instruments (Figure). After the torsion test, all fragments presented typical features of shear failure, including abrasion marks and microscopic fibrous dimples at the center of rotation (Figure A, B, C and D). Additionally, in lateral view, it was possible to note a greater deformation of the spiral flutes of One G instruments when compared to R-Pilot (Figure E and F).

The results obtained for One $G$ instruments suggest that they are more flexible than R-Pilot because of the lower torsional strength and greater angle of rotation to failure. The greater angle of rotation of One G could indicate plastic deformation and the risk of imminent instrument failure. ${ }^{35}$ On the other hand, the lower torsional strength could lead to easy plastic deformation ${ }^{35}$ when compared to R-Pilot. Moreover, the greater flexibility observed could suggest that One G is more resistant to cyclic fatigue than R-Pilot. However, Yilmaz et al. ${ }^{17}$ showed that R-Pilot presents significantly greater cyclic fatigue strength than does One G. Therefore, the results of the torsion test cannot determine the cyclic fatigue behavior of the instruments. The greater cyclic fatigue strength of R-Pilot is related to the reciprocating motion. ${ }^{36,37}$ Reciprocating motion probably compensates for the lower flexibility of R-Pilot instruments and could reduce the risk of instrument fracture by torsion in cases of curved and constricted canals. Therefore, the clinician should know the torsional and cyclic fatigue strengths to choose a suitable glide path instrument and to perform a safe glide path procedure.

The torsion test is a laboratory test that provides accurate information about the maximum torsional strength and angle of rotation supported by each instrument before failure. This test provides a standard high torsional stress for all groups, which is fundamental to ensure accurate results. ${ }^{23}$ The torsion test results could determine which instrument could be more resistant when the glide path procedure is used in a constricted canal. ${ }^{21-23}$ Therefore, the authors suggest that future randomized clinical trials should be conducted to evaluate whether the different torsional strength and angle of rotation between these instruments could clinically affect their susceptibility to fracture and the success of the glide path procedure.

\section{Conclusions}

In conclusion, R-Pilot (M-wire NiTi alloy) had the highest torsional strength, metal mass volume, and cross-sectional area. However, One G (superelastic NiTi alloy) had higher angle of rotation to fracture. 
Torsional fatigue strength of reciprocating and rotary pathfinding instruments manufactured from different NiTi alloys

\section{References}

1. Patiño PV, Biedma BM, Liébana CR, Cantatore G, Bahillo JG. The influence of a manual glide path on the separation rate of NiTi rotary instruments. J Endod. 2005 Feb;31(2):114-6. https://doi.org/10.1097/01.don.0000136209.28647.13

2. De-Deus G, Belladonna FG, Souza EM, Alves VO, Silva EJ, Rodrigues E, et al. Scouting Ability of 4 Pathfinding Instruments in Moderately Curved Molar Canals. J Endod. 2016 Oct;42(10):1540-4. https://doi.org/10.1016/i.joen.2016.07.001

3. West JD. The endodontic Glidepath: "Secret to rotary safety". Dent Today. 2010 Sep;29(9):86.

4. Ruddle CJ, Machtou P, West JD. Endodontic canal preparation: innovations in glide path management and shaping canals. Dent Today. 2014 Jul;33(7):118-23.

5. D'Amario M, Baldi M, Petricca R, De Angelis F, El Abed R, D'Arcangelo C. Evaluation of a new nickel-titanium system to create the glide path in root canal preparation of curved canals. J Endod. 2013 Dec;39(12):1581-4. https://doi.org/10.1016/i.joen.2013.06.037

6. Elnaghy AM, Elsaka SE. Evaluation of root canal transportation, centering ratio, and remaining dentin thickness associated with ProTaper Next instruments with and without glide path. J Endod. 2014 Dec;40(12):2053-6. https://doi.org/10.1016/i.joen.2014.09.001

7. Berutti E, Cantatore G, Castellucci A, Chiandussi G, Pera F, Migliaretti G, et al. Use of nickel-titanium rotary PathFile to create the glide path: comparison with manual preflaring in simulated root canals. J Endod. 2009 Mar;35(3):408-12. https://doi.org/10.1016/i.joen.2008.11.021

8. Pasqualini D, Bianchi CC, Paolino DS, Mancini L, Cemenasco A, Cantatore G, et al. Computed micro-tomographic evaluation of glide path with nickel-titanium rotary PathFile in maxillary first molars curved canals. J Endod. 2012 Mar;38(3):389-93. https://doi.org/10.1016/i.joen.2011.11.011

9. Gambarini G, Plotino G, Sannino G, Grande NM, Giansiracusa A, Piasecki L, et al. Cyclic fatigue of instruments for endodontic glide path. Odontology. 2015 Jan;103(1):56-60. https://doi.org/10.1007/s10266-013-0138-x

10. Serefoglu B, Kaval ME, Micoogullari Kurt S, Çalişkan MK. Cyclic Fatigue Resistance of Novel Glide Path Instruments with Different Alloy Properties and Kinematics. J Endod. 2018 Sep;44(9):1422-4. https://doi.org/10.1016/i.joen.2018.05.013

11. Uslu G, Özyürek T, Yılmaz K, Gündoğar M. Cyclic fatigue resistance of R-Pilot, HyFlex EDM and PathFile nickel-titanium glide path files in artificial canals with double (S-shaped) curvature. Int Endod J. 2018 May;51(5):584-9. https://doi.org/10.1111/iej.12846

12. Wycoff RC, Berzins DW. An in vitro comparison of torsional stress properties of three different rotary nickel-titanium files with a similar cross-sectional design. J Endod. 2012 Aug;38(8):1118-20. https://doi.org/10.1016/i.joen.2012.04.022

13. Arias A, Singh R, Peters OA. Differences in torsional performance of single-and multiple-instrument rotary systems for glide path preparation. Odontology. 2016 May; 104(2):192-8. https://doi.org/10.1007/s10266-015-0199-0

14. Sattapan B, Nervo GJ, Palamara JE, Messer HH. Defects in rotary nickel-titanium files after clinical use. J Endod. 2000 Mar;26(3):161-5. https://doi.org/10.1097/00004770-200003000-00008

15. Karataş E, Arslan H, Büker M, Seçkin F, Çapar ID. Effect of movement kinematics on the cyclic fatigue resistance of nickel-titanium instruments. Int Endod J. 2016 Apr;49(4):361-4. https://doi.org/10.1111/iej.12453

16. Özyürek T, Uslu G, Gündoğar M, Yllmaz K, Grande NM, Plotino G. Comparison of cyclic fatigue resistance and bending properties of two reciprocating nickel-titanium glide path files. Int Endod J. 2018 Sep;51(9):1047-52. https://doi.org/10.1111/iej.12911

17. Y.lmaz K, Uslu G, Özyürek T. In vitro comparison of the cyclic fatigue resistance of HyFlex EDM, One G, and ProGlider nickel titanium glide path instruments in single and double curvature canals. Restor Dent Endod. 2017 Nov;42(4):282-9. https://doi.org/10.5395/rde.2017.42.4.282

18. Uslu G, Özyürek T, İnan U. Comparison of Cyclic Fatigue Resistance of ProGlider and One G Glide Path Files. J Endod. 2016 Oct;42(10):1555-8. https://doi.org/10.1016/i.joen.2016.07.012

19. Gunes B, Yesildal Yeter K. Effects of Different Glide Path Files on Apical Debris Extrusion in Curved Root Canals. J Endod. 2018 Jul;44(7):1191-4. https://doi.org/10.1016/i.joen.2018.04.012

20. Elnaghy AM, Elsaka SE. Evaluation of the mechanical behaviour of PathFile and ProGlider pathfinding nickel-titanium rotary instruments. Int Endod J. 2015 Sep;48(9):894-901. https://doi.org/10.1111/iej.12386

21. Pedullà E, Lo Savio F, Boninelli S, Plotino G, Grande NM, La Rosa G, et al. Torsional and cyclic fatigue resistance of a new nickel-titanium instrument manufactured by electrical discharge machining. J Endod. 2016 Jan;42(1):156-9. https://doi.org/10.1016/j.joen.2015.10.004

22. Alcalde MP, Tanomaru-Filho M, Bramante CM, Duarte MA, Guerreiro-Tanomaru JM, Camilo-Pinto J, et al. Cyclic and torsional fatigue resistance of reciprocating single files manufactured by different nickel-titanium alloys. J Endod. 2017 Jul;43(7):1186-91. https://doi.org/10.1016/i.joen.2017.03.008

23. Bahia MG, Melo MC, Buono VT. Influence of simulated clinical use on the torsional behavior of nickel-titanium rotary endodontic instruments. Oral Surg Oral Med Oral Pathol Oral Radiol Endod. 2006 May;101(5):675-80. https://doi.org/10.1016/i.tripleo.2005.04.019

24. Alcalde MP, Duarte MA, Bramante CM, Tanomaru-Filho M, Vasconcelos BC, Só MV, et al. Torsional fatigue resistance of pathfinding instruments manufactured from several nickel-titanium alloys. Int Endod J. 2018 Jun;51(6):697-704. https://doi.org/10.1111/iej.12879

25. Berutti E, Negro AR, Lendini M, Pasqualini D. Influence of manual preflaring and torque on the failure rate of ProTaper rotary instruments. J Endod. 2004 Apr;30(4):228-30. https://doi.org/10.1097/00004770-200404000-00011 
26. Ha JH, Park SS. Influence of glide path on the screw-in effect and torque of nickel-titanium rotary files in simulated resin root canals. Restor Dent Endod. 2012 Nov;37(4):215-9. https://doi.org/10.5395/rde.2012.37.4.215

27. Capar ID, Kaval ME, Ertas H, Sen BH. Comparison of the cyclic fatigue resistance of 5 different rotary pathfinding instruments made of conventional nickel-titanium wire, M-wire, and controlled memory wire. J Endod. 2015 Apr;41(4):535-8. https://doi.org/10.1016/i.joen.2014.11.008

28. Goo HJ, Kwak SW, Ha JH, Pedullà E, Kim HC. Mechanical Properties of Various Heat-treated Nickel-titanium Rotary Instruments. J Endod. 2017 Nov;43(11):1872-7. https://doi.org/10.1016/i.joen.2017.05.025

29. Lee JY, Kwak SW, Ha JH, Abu-Tahun IH, Kim HC. Mechanical properties of various glide path preparation nickel-titanium rotary instruments. J Endod. 2019 Feb;45(2):199-204. https://doi/org/10.1016/i.joen.2018.10.017

30. Santos CB, Simões-Carvalho M, Perez R, Vieira VT, Antunes HS, Cavalcante DF, et al. Torsional fatigue resistance of R-Pilot and WaveOne Gold Glider NiTi glide path reciprocating systems. Int Endod J. 2019 Jun;52(6):874-879. https://doi/org/10.1111/iej.13068

31. Viana AC, Melo MCC, Bahia MGA, Lopes Buono VT. Relationship between flexibility and physical, chemical, and geometric characteristics of rotary nickel-titanium instruments. Oral Surg Oral Med Oral Pathol Oral Radiol Endod. 2010 Oct;110(4):527-33. https://doi.org/10.1016/i.tripleo.2010.05.006

32. Baek SH, Lee CJ, Versluis A, Kim BM, Lee W, Kim HC. Comparison of torsional stiffness of nickel-titanium rotary files with different geometric characteristics. J Endod. 2011 Sep;37(9):1283-6. https://doi.org/10.1016/i.joen.2011.05.032

33. Sousa-Neto MD, Silva-Sousa YC, Mazzi-Chaves JF, et al. Root canal preparation using micro-computed tomography analysis: a literature review. Braz Oral Res. 2018 Oct;18;32(1):e66. https://doi.org/10.1590/1807-3107bor-2018.vol32.0066

34. Zhang EW, Cheung GS, Zheng YF. A mathematical model for describing the mechanical behaviour of root canal instruments. Int Endod J. 2011 Jan;44(1):72-6. https://doi.org/10.1111/j.1365-2591.2010.01801.x

35. Ninan E, Berzins DW. Torsion and bending properties of shape memory and superelastic nickel-titanium rotary instruments. J Endod. 2013 Jan;39(1):101-4. https://doi.org/10.1016/i.joen.2012.08.010

36. Kim HC, Kwak SW, Cheung GS, Ko DH, Chung SM, Lee W. Cyclic fatigue and torsional resistance of two new nickel-titanium instruments used in reciprocation motion: reciproc versus WaveOne. J Endod. 2012 Apr;38(4):541-4. https://doi.org/10.1016/i.joen.2011.11.014

37. Çapar ID, Arslan H. A review of instrumentation kinematics of engine-driven nickel-titanium instruments. Int Endod J. 2016 Feb;49(2):119-35. https://doi.org/10.1111/iej.12432 